\title{
How can aprotic ionic liquids affect enzymatic enantioselectivity?
}

\author{
Hidetaka Noritomi ${ }^{1}$, Hideki Chiba ${ }^{1}$, Manabu Kikuta ${ }^{2}$, Satoru Kato ${ }^{1}$ \\ ${ }^{1}$ Department of Applied Chemistry, Tokyo Metropolitan University, Tokyo, Japan \\ ${ }^{2}$ Dai-Ichi Kogyo Seiyaku Co., Ltd., Oogawara-cho, Kisshoin, Kyoto, Japan \\ Email: noritomi@tmu.ac.jp
}

Received 1 August 2013; revised 29 August 2013; accepted 15 September 2013

Copyright (C) 2013 Hidetaka Noritomi et al. This is an open access article distributed under the Creative Commons Attribution License, which permits unrestricted use, distribution, and reproduction in any medium, provided the original work is properly cited.

\begin{abstract}
The enantioselectivity of $\alpha$-chymotrypsin in the esterification of $\mathrm{N}$-acetyl-tryptophan with ethanol was examined in aprotic ionic liquids. The enantioselectivity was found to be strongly affected by a kind of solvent, water content, and reaction temperature. The $\left(k_{\mathrm{cat}} / K_{\mathrm{M}}\right)_{\mathrm{L}} /\left(\boldsymbol{k}_{\mathrm{cat}} / K_{\mathrm{M}}\right)_{\mathrm{D}}$ ratio in 1-ethyl-3-methylimidazolium bis(fluorosulfonyl)imide $\left(\left[\mathrm{C}_{2} \mathrm{mim}\right][\mathrm{FSI}]\right)$ containing $1.0 \%(v / v)$ water at $25^{\circ} \mathrm{C}$ exhibits 32,000 , while that in 1-ethyl-3-methylimidazolium tetrafluoroborate $\left(\left[\mathrm{C}_{2} \mathrm{mim}\right]\left[\mathrm{BF}_{4}\right]\right)$ containing $1.0 \%(v / v)$ water at $25^{\circ} \mathrm{C}$ shows 190. The $\left(k_{\text {cat }} / K_{\mathrm{M}}\right)_{\mathrm{L}} /\left(k_{\text {cat }} / K_{\mathrm{M}}\right)_{\mathrm{D}}$ ratio in $\left[\mathrm{C}_{2} \mathrm{mim}\right]$ $\left[\mathrm{BF}_{4}\right]$ at $25^{\circ} \mathrm{C}$ varies from 190 at $1.0 \%(v / v)$ water to 65000 at $5.0 \%(v / v)$ water. Moreover, the $\left(k_{\mathrm{cat}} / K_{\mathrm{M}}\right)_{\mathrm{L}} /$ $\left(k_{\text {cat }} / K_{\mathrm{M}}\right)_{\mathrm{D}}$ ratio in [C $\left.\mathrm{C}_{2} \mathrm{mim}\right][\mathrm{FSI}]$ containing $5.0 \%(v / v)$ water can be forced to induce a 7-fold increase simply by switching from $25^{\circ} \mathrm{C}$ to $40^{\circ} \mathrm{C}$. The enantioselectivity tended to correlate with enzyme reactivity in ionic liquids.
\end{abstract}

Keywords: $\alpha$-Chymotrypsin; Enantioselectivity; Esterification; Aprotic Ionic Liquid

\section{INTRODUCTION}

Enantioselective synthesis is a key process in modern chemistry, and is particularly important in the field of pharmaceuticals, as the different enantiomers or diastereomers of a molecule often have different biological activities. Therefore, the enantioselectivity is the most valuable feature of enzymes from the standpoint of their application as practical catalysts. In nonaqueous reaction system, the enantioselectivity of enzymes has been markedly dependent upon organic solvents [1-5]. On the other hand, enzymatic reactions in hydrophilic solvents have the advantage of the solubility of a variety of substrates, including amino acid derivatives, which are poorly solu- ble in hydrophobic solvents [5]. However, when a hydrophilic solvent is used as a reaction medium, the enzyme molecule directly contacts with the solvent, and thereby its activity and enantioselectivity are strongly influenced by the nature of the solvent [1,2]. Moreover, as the enzyme is insoluble in nonaqueous media, which are $100 \%$ organic solvent media or aqueous solutions containing high amount of organic solvents, and is suspended, the reactivity of enzymes tends to be strongly influenced by the dispersion state of enzymes.

Ionic solvent that is liquid at room temperature has attracted increasing attention as innovative non-aqueous media for the chemical processes because of the lack of vapor pressure, the thermal stability, and the high polarity [6]. Chemical and physical properties of ionic liquids can be changed by the appropriate modification of organic cations and anions, which are constituents of ionic liquids. Biotransformation in ionic liquids has extensively been studied [6,7]. In our previous study, we have reported that protease-catalyzed esterification of amino acid and peptide synthesis are highly enhanced in ionic liquids, compared to organic solvents $[8,9]$.

In the present study, we have addressed a question how aprotic ionic liquids can affect the enantioselectivity of enzymatic esterification. We have examined proteasecatalyzed esterification of $\mathrm{N}$-acetylated amino acid with ethanol in partially or perfectly water-miscible ionic liquids. We employed bovine pancreas $\alpha$-chymotrypsin as a model enzyme, since it is well investigated regarding its structure, functions, and properties [10].

\section{MATERIAL AND METHODS}

\subsection{Material}

$\alpha$-Chymotrypsin (EC 3.4.21.1 from bovine pancreas)(type II, 52 units $/ \mathrm{mg}$ solid) was purchased from Sigma-Aldrich Co. (St. Louis, USA). N-Acetyl-L-tryptophan ethyl ester 
( $N$-Ac-L-Trp-OEt), $N$-acetyl-L-tryptophan ( $N$-Ac-L-Trp$\mathrm{OH})$, and $N$-acetyl-D-tryptophan ( $N$-Ac-D-Trp-OH) were also from Sigma-Aldrich Co. (St. Louis, USA). 1-Ethyl3-methylimidazolium bis(fluorosulfonyl)imide ([ $\left.\mathrm{C}_{2} \mathrm{mim}\right]$ [FSI]) (99\% purity) was supplied from Dai-Ichi Kogyo Seiyaku Co. (Kyoto, Japan). 1-Ethyl-3-methylimidazolium tetrafluoroborate $\left(\left[\mathrm{C}_{2} \mathrm{mim}\right]\left[\mathrm{BF}_{4}\right]\right)(99 \%$ purity), 1-butyl3-methylimidazolium hexafluorophosphate $\left(\left[\mathrm{C}_{4} \mathrm{mim}\right]\left[\mathrm{PF}_{6}\right]\right)$ ( $99 \%$ purity), and 1-butyl-3-methylimidazolium bis (trifluoromethylsulfonyl)imide ([C $\left.\left.\mathrm{C}_{4} \mathrm{mim}\right][\mathrm{TFSI}]\right)(99 \%$ purity) were obtained from Kanto Chemical Co. (Tokyo, Japan). The structures of solvents used in the present work are shown in Figure 1. All solvents used were of guaranteed grade, and were used without further purification.

\subsection{Kinetic Measurements}

The standard reaction for esterification synthesis was carried out as follows: Five hundred micro liter of ionic liquid or organic solvent containing a given amount of water, 5 - $25 \mathrm{mM} \mathrm{N}$-Ac-L-Trp-OH or 5 - $25 \mathrm{mM} \mathrm{N}$-AcD-Trp-OH, $1000 \mathrm{mM}$ ethanol, and $74 \mathrm{mM}$ acetanilide was added to $1 \mathrm{mg}$ of $\alpha$-chymotrypsin in a $4 \mathrm{~mL}$ screwcap vial. The vial was shaken at $120 \mathrm{rpm}$ and $25^{\circ} \mathrm{C}$. The amounts of the reaction components were determined with HPLC (Shimadzu LC-10A) ( Shimadzu Co., Kyoto, Japan) using a TSK-GEL ODS-80TM column (Tosoh Co., Tokyo, Japan) eluted with water-methanol (5:5 by volume) at $1.0 \mathrm{~mL} / \mathrm{min}$ with detection at $290 \mathrm{~nm}$. Acetanilide was used as an internal standard.

\section{RESULTS AND DISCUSSION}

\subsection{Effect of Reaction Medium on $\alpha$-Chymotrypsin-Catalyzed Esterification}

In the present work, $\alpha$-chymotrypsin-catalyzed esterification was examined as shown in Figure 2. The esterification obeys ping-pong kinetics [11,12]. It is assumed that the esterification proceeds through the steady state approximation. The rate of $N$-acetyl-tryptophan (Ac-Trp$\mathrm{OH})$ is given as

\begin{tabular}{|c|c|c|c|}
\hline Solvent & Structure & m. p. $\left({ }^{\circ} \mathrm{C}\right)$ & $\begin{array}{c}\text { Water } \\
\text { miscibility }\end{array}$ \\
\hline [C2mim] [BF4] & & 15.0 & Miscible \\
\hline [C2mim][FSI] & & -12.9 & $\begin{array}{c}\text { Partially } \\
\text { miscible }\end{array}$ \\
\hline [C4mim][PF6] & & 6.5 & Immiscible \\
\hline [C4mim][TFSI] & & -16.2 & Immiscible \\
\hline THF & & 66 & Miscible \\
\hline
\end{tabular}

Figure 1. Structures of solvents used in the present work.

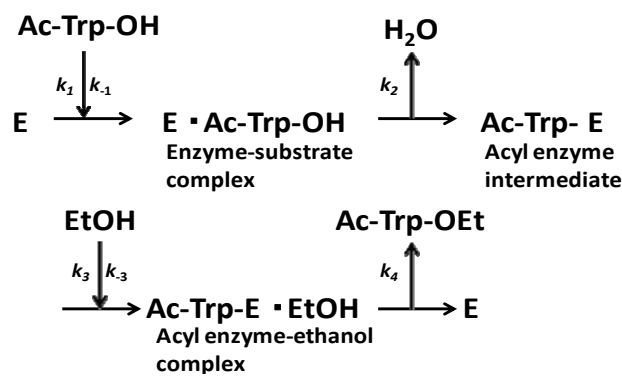

Figure 2. $\alpha$-Chymotrypsin-catalyzed esterification of $\mathrm{N}$-acetyltryptophan (Ac-Trp-OH) with ethanol (EtOH) to $N$-acetyltryptophan ethylester (AcTrp-OEt).

$$
\begin{aligned}
& \mathrm{d}[\mathrm{Ac}-\operatorname{Trp}-\mathrm{OH}] / \mathrm{dt} \\
& =k_{-1}[\mathrm{E} \cdot \mathrm{Ac}-\operatorname{Trp}-\mathrm{OH}]-k_{1}[\mathrm{E}][\mathrm{Ac}-\mathrm{Trp}-\mathrm{H}]
\end{aligned}
$$

where $\mathrm{E}$ and $\mathrm{E} \cdot \mathrm{Ac}-\mathrm{Trp}-\mathrm{OH}$ are $\alpha$-chymotrypsin and enzyme-substrate complex, respectively. Similarly, the rates of E, enzyme-subatrate complex (E・Ac-Trp-OH ), acyl enzyme intermediate (Ac-Trp-E), acyl enzyme-ethanol complex (Ac-Trp-E-EtOH), $\mathrm{H}_{2} \mathrm{O}$, and $N$-acetyl-tryptophan ethyl ester (Ac-Trp-OEt) are as follows:

$$
\begin{aligned}
& \mathrm{d}[\mathrm{E}] / \mathrm{d} t=k_{-1}[\mathrm{E} \cdot \mathrm{Ac}-\mathrm{Trp}-\mathrm{OH}] \\
& +k_{4}[\mathrm{Ac}-\mathrm{Trp}-\mathrm{E} \cdot \mathrm{EtOH}]-k_{1}[\mathrm{E}][\mathrm{Ac}-\mathrm{Trp}-\mathrm{OH}] \\
& \mathrm{d}[\mathrm{E} \cdot \mathrm{Ac}-\mathrm{Trp}-\mathrm{OH}] / \mathrm{d} t \\
& =k_{1}[\mathrm{E}][\mathrm{Ac}-\mathrm{Trp}-\mathrm{OH}]-\left(k_{-1}+k_{2}\right)[\mathrm{E} \cdot \mathrm{Ac}-\mathrm{Trp}-\mathrm{OH}] \\
& \mathrm{d}[\mathrm{Ac}-\mathrm{Trp}-\mathrm{E}] / \mathrm{d} t=k_{2}[\mathrm{E} \cdot \mathrm{Ac}-\mathrm{Trp}-\mathrm{OH}] \\
& -k_{3}[\mathrm{Ac}-\mathrm{Trp}-\mathrm{E}][\mathrm{EtOH}]+k_{-3}[\mathrm{Ac}-\mathrm{Trp}-\mathrm{E} \cdot \mathrm{EtOH}] \\
& \mathrm{d}[\mathrm{Ac}-\mathrm{Trp}-\mathrm{E} \cdot \mathrm{EtOH}] / \mathrm{d} t=k_{3}[\mathrm{Ac}-\mathrm{Trp}-\mathrm{E}][\mathrm{EtOH}] \\
& -\left(k_{-3}+k_{4}\right)[\mathrm{Ac}-\mathrm{Trp}-\mathrm{E} \cdot \mathrm{EtOH}] \\
& \quad \mathrm{d}\left[\mathrm{H}_{2} \mathrm{O}\right] / \mathrm{d} t=k_{2}[\mathrm{E} \cdot \mathrm{Ac}-\operatorname{Trp}-\mathrm{OH}] \\
& \mathrm{d}[\mathrm{Ac}-\operatorname{Trp}-\mathrm{OEt}] / \mathrm{d} t=k_{4}[\mathrm{Ac}-\mathrm{Trp}-\mathrm{E} \cdot \mathrm{EtOH}]
\end{aligned}
$$

Since all enzyme present is either free or complexed,

$$
\begin{aligned}
& {[\mathrm{E}]_{0}=[\mathrm{E}]+[\mathrm{E} \cdot \mathrm{Ac}-\mathrm{Trp}-\mathrm{OH}]} \\
& +[\mathrm{Ac}-\mathrm{Trp}-\mathrm{E}]+[\mathrm{Ac}-\mathrm{Trp}-\mathrm{E} \cdot \mathrm{EtOH}]
\end{aligned}
$$

where $[E]_{0}$ is the total concentration of enzyme in the system. Assuming the steady state approximation on the rate of E-Ac-Trp-OH, from Eq.3

$$
\begin{aligned}
& \mathrm{d}[\mathrm{E} \cdot \mathrm{Ac}-\mathrm{Trp}-\mathrm{OH}] / \mathrm{d} t=k_{1}[\mathrm{E}][\mathrm{Ac}-\mathrm{Trp}-\mathrm{OH}] \\
& -\left(k_{-1}+k_{2}\right)[\mathrm{E} \cdot \mathrm{Ac}-\mathrm{Trp}-\mathrm{OH}]=0 \\
& K s_{1}=[\mathrm{E}][\mathrm{Ac}-\operatorname{Trp}-\mathrm{OH}] /[\mathrm{E} \cdot \mathrm{Ac}-\operatorname{Trp}-\mathrm{OH}] \\
& =\left(k_{-1}+k_{2}\right) / k_{1}
\end{aligned}
$$


where $K s_{1}$ is the dissociation constant of E•Ac-Trp-OH. Assuming $\mathrm{d}\left[\mathrm{H}_{2} \mathrm{O}\right] / \mathrm{d} t=\mathrm{d}[\mathrm{Ac}-\mathrm{Trp}-\mathrm{OEt}] / \mathrm{d} t$, from Eqs.6 and 7,

$[\mathrm{Ac}-\mathrm{Trp}-\mathrm{E} \cdot \mathrm{EtOH}]=\left(k_{2} / k_{4}\right)[\mathrm{E} \cdot \mathrm{Ac}-\mathrm{Trp}-\mathrm{OH}]$

Assuming the steady state approximation on the rate of Ac-Trp-E·EtOH, from Eq.5

$$
\begin{aligned}
& \mathrm{d}[\mathrm{Ac}-\mathrm{Trp}-\mathrm{E} \cdot \mathrm{EtOH}] / \mathrm{d} t \\
& =k_{3}[\mathrm{AcE}][\mathrm{EtOH}]-\left(k_{-3}+k_{4}\right)[\mathrm{Ac}-\mathrm{Trp}-\mathrm{E} \cdot \mathrm{EtOH}]=0 \\
& \mathrm{Ks}_{2}=[\mathrm{Ac}-\mathrm{Trp}-\mathrm{E}][\mathrm{EtOH}] /[\mathrm{Ac}-\mathrm{Trp}-\mathrm{E} \cdot \mathrm{EtOH}] \\
& =\left(k_{-3}+k_{4}\right) / k_{3}
\end{aligned}
$$

where $K s_{2}$ is the dissociation constant of Ac-Trp-E・EtOH. From Eq.13

$$
[\mathrm{Ac}-\mathrm{Trp}-\mathrm{E}]=K s_{2}[\mathrm{Ac}-\mathrm{Trp}-\mathrm{E} \cdot \mathrm{EtOH}] /[\mathrm{EtOH}]
$$

\section{From Eq.8}

$$
\begin{aligned}
& {[\mathrm{E}]=[\mathrm{E}]_{0}-[\mathrm{E} \cdot \mathrm{Ac}-\mathrm{Trp}-\mathrm{OH}]} \\
& -[\mathrm{Ac}-\mathrm{Trp}-\mathrm{E}]-[\mathrm{Ac}-\mathrm{Trp}-\mathrm{E} \cdot \mathrm{EtOH}]
\end{aligned}
$$

Substituting Eqs.11 and 14 into Eq.15,

\begin{tabular}{|c|c|c|c|c|c|}
\hline solvent & isomer & $k_{\text {cat }}$ & $K_{\mathrm{M}}$ & $k_{\mathrm{cat}} / K_{\mathrm{M}}$ & enantioselectivity \\
\hline & & $\left(\mathrm{min}^{-1}\right)$ & $(\mathrm{mM})$ & $\left(\mathrm{M}^{-1} \cdot \mathrm{min}^{-1}\right)$ & $\left(k_{\mathrm{cat}} / K_{\mathrm{M}}\right)_{\mathrm{L}} /\left(k_{\mathrm{cat}} / K_{\mathrm{M}}\right)_{\mathrm{D}}$ \\
\hline \multirow[t]{2}{*}[\mathrm{C}_{2}\mathrm{mim}]{$\left[\mathrm{BF}_{4}\right]$} & $\mathrm{L}$ isomer & 0.3 & 7.4 & 41 & 65000 \\
\hline & $\mathrm{D}$ isomer & 0.0000063 & 10 & 0.00063 & \\
\hline \multirow[t]{2}{*}[\mathrm{C}_{2}\mathrm{mim}]{$[\mathrm{FSI}]$} & $\mathrm{L}$ isomer & 0.26 & 22 & 12 & 200 \\
\hline & $\mathrm{D}$ isomer & 0.00078 & 13 & 0.06 & \\
\hline \multirow[t]{2}{*}[\mathrm{C}_{4}\mathrm{mim}]{$\left[\mathrm{PF}_{6}\right]$} & $\mathrm{L}$ isomer & 0.011 & 4.3 & 2.5 & 781 \\
\hline & $\mathrm{D}$ isomer & 0.000051 & 16 & 0.0032 & \\
\hline \multirow[t]{2}{*}[\mathrm{C}_{4}\mathrm{mim}]{$[\mathrm{TFSI}]$} & $\mathrm{L}$ isomer & 0.0065 & 12 & 0.54 & 8600 \\
\hline & $\mathrm{D}$ isomer & 0.00000063 & 10 & 0.000063 & \\
\hline \multirow[t]{2}{*}{ THF } & $\mathrm{L}$ isomer & 0.16 & 18 & 8.9 & 1400 \\
\hline & $\mathrm{D}$ isomer & 0.0003 & 47 & 0.0064 & \\
\hline
\end{tabular}

$$
\begin{aligned}
& {[\mathrm{E}]=[\mathrm{E}]_{0}-[\mathrm{E} \cdot \mathrm{Ac}-\mathrm{Trp}-\mathrm{OH}]-\left(k_{2} K s_{2} / k_{4}[\mathrm{EtOH}]\right)} \\
& {[\mathrm{E} \cdot \mathrm{Ac}-\mathrm{Trp}-\mathrm{OH}]-\left(k_{2} / k_{4}\right)[\mathrm{E} \cdot \mathrm{Ac}-\mathrm{Trp}-\mathrm{OH}]}
\end{aligned}
$$

Substituting Eq.16 into Eq.10,

$$
\begin{aligned}
& {[\mathrm{E} \cdot \mathrm{Ac}-\mathrm{Trp}-\mathrm{OH}] } \\
= & k_{4}[\mathrm{EtOH}][\mathrm{E}]_{0}[\mathrm{Ac}-\mathrm{Trp}-\mathrm{OH}] \\
& /\left\{\left(k_{2}+k_{4}\right)[\mathrm{EtOH}]+k_{2} K s_{2}\right\} \\
& /\left\{k_{4} K s_{1}[\mathrm{EtOH}] /\left\{\left(k_{2}+k_{4}\right)[\mathrm{EtOH}]+k_{2} K s_{2}\right\}\right. \\
& +[\mathrm{Ac}-\mathrm{Trp}-\mathrm{OH}]\}
\end{aligned}
$$

Table 1. Kinetic parameters of $\alpha$-chymotrypsin in esterification in various solvents ${ }^{\mathrm{a}}$.

${ }^{\mathrm{a}}$ The enzyme was placed in the solvent containing 5\% (v/v) water, 5 - $25 \mathrm{mM} \mathrm{N}$-Ac-Trp-OH, and $1000 \mathrm{mM}$ EtOH, and the resulting mixture was shaken at 120 $\mathrm{rpm}$ and $25^{\circ} \mathrm{C}$. The reaction rates of ester formation were measured, and kinetic parameters were derived by correlating resultant reaction rates with HanesWoolf plot.
Because of excess $[\mathrm{EtOH}],\left(k_{2}+k_{4}\right)[\mathrm{EtOH}]$ is much greater than $k_{2} K_{\mathrm{S} 2}$. Consequently,

The reaction rate $v$ is

$$
\begin{aligned}
& v=\mathrm{d}[\mathrm{Ac}-\operatorname{Trp}-\mathrm{OEt}] / \mathrm{d} t=\mathrm{d}\left[\mathrm{H}_{2} \mathrm{O}\right] / \mathrm{d} t \\
& =k_{2}[\mathrm{E} \cdot \mathrm{Ac}-\mathrm{Trp}-\mathrm{OH}] \\
& =\left\{k_{2} k_{4} /\left(k_{2}+k_{4}\right)\right\}[\mathrm{E}]_{0} \\
& {[\mathrm{Ac}-\mathrm{Trp}-\mathrm{OH}] /\left\{k_{4} K s_{1} /\left(k_{2}+k_{4}\right)+[\mathrm{Ac}-\mathrm{Trp}-\mathrm{OH}]\right\}} \\
& =k_{\text {cat }}[\mathrm{E}]_{0}[\mathrm{Ac}-\operatorname{Trp}-\mathrm{OH}] /\left(K_{\mathrm{M}}+[\mathrm{Ac}-\mathrm{Trp}-\mathrm{OH}]\right)
\end{aligned}
$$

where

$$
\begin{gathered}
k_{\text {cat }}=k_{2} k_{4} /\left(k_{2}+k_{4}\right) \\
K_{\mathrm{M}}=k_{4} K s_{1} /\left(k_{2}+k_{4}\right)=\left(k_{-1}+k_{2}\right) k_{4} / k_{1}\left(k_{2}+k_{4}\right)
\end{gathered}
$$

Thus, the reaction rate $v$ corresponds upon MichaelisMenten type model.

The performances of enzymes such as activity and specificity in non-aqueous media markedly depend upon the nature of solvents [1,2]. In order to assess the effect of reaction media on kinetic parameters of $\alpha$-chymotrypsin, the reaction rate in ionic liquids and organic solvents containing 5\% $(v / v)$ water was measured at different concentrations of $N$-Ac-L-Trp-OEt or $N$-Ac-D-Trp-OEt at $25^{\circ} \mathrm{C}$. The kinetic parameters, $k_{\text {cat }}$ and $K_{\mathrm{M}}$, were derived by correlating resultant reaction rates with HanesWoolf plot [12]. Table 1 shows kinetic parameters in ionic liquids and THF. Since the magnitude of $k_{\text {cat }}$ in the esterification of natural substrate $N$-Ac-L-Trp-OH with $\mathrm{EtOH}$ was much greater than that in the esterification of non-natural substrate $N$-Ac-D-Trp-OH with $\mathrm{EtOH}$, the

$$
\begin{aligned}
& {[\mathrm{E} \cdot \mathrm{Ac}-\mathrm{Trp}-\mathrm{OH}]=\left\{k_{4} /\left(k_{2}+k_{4}\right)\right\}[\mathrm{E}]_{0}} \\
& {[\mathrm{Ac}-\mathrm{Trp}-\mathrm{OH}] /\left\{k_{4} K s_{1} /\left(k_{2}+k_{4}\right)+[\mathrm{Ac}-\mathrm{Trp}-\mathrm{OH}]\right\}}
\end{aligned}
$$


specificity constant $k_{\text {cat }} / K_{\mathrm{M}}$ of $\mathrm{L}$ isomer was larger than that of $\mathrm{D}$ isomer. This result indicates that the enantiopreferance of $\alpha$-chymotrypsin in ionic liquids and THF is similar to that in aqueous solutions. The $\left(k_{\text {cat }} / K_{\mathrm{M}}\right)_{\mathrm{L}}$ in $\left[\mathrm{C}_{2} \mathrm{mim}\right]\left[\mathrm{BF}_{4}\right]$ system was greatest regarding reaction systems used in the present work. We have reported that $\left[\mathrm{C}_{2} \mathrm{mim}\right]\left[\mathrm{BF}_{4}\right]$ has little denaturation effect on proteins in aqueous media, and exhibits high thermal stabilization and refolding effects on proteins [13]. Moreover, inspecttion of Table 1 reveals that the enantioselectivity, expressed as $\left(k_{\text {cat }} / K_{\mathrm{M}}\right)_{\mathrm{L}} /\left(k_{\text {cat }} / K_{\mathrm{M}}\right)_{\mathrm{D}}$, can be forced to span a 325-fold range simply by switching from one ionic liquid to another under otherwise identical conditions.

\subsection{Effect of Water Content on Enantioselectivity of $\alpha$-Chymotrypsin in Ionic Liquids}

A common thread in all studies of enzymes in anhydrous solvents is that the amount of water associated with the enzyme is a key determinant of the properties (e.g. activity, stability, and specificity) that the enzyme exhibits [1]. Moreover, water can act as a substrate in reactions using hydrolytic enzymes. In order to elucidate the relationship between the enantioselectivity of $\alpha$-chymotrypsin and water content in ionic liquids, the $\left(k_{\text {cat }} / K_{\mathrm{M}}\right)_{\mathrm{L}} /\left(k_{\text {cat }} / K_{\mathrm{M}}\right)_{\mathrm{D}}$ ratio was investigated at different water contents and $25^{\circ} \mathrm{C}$. Figure 3 shows the enantioselectivity of $\alpha$-chymotrypsin in the esterification of $N$-Ac-Trp-OH with $\mathrm{EtOH}$ in ionic liquids and THF at different water contents. The enantioselectivity of $\alpha$-chymotrypsin in $\left[\mathrm{C}_{2} \mathrm{mim}\right]\left[\mathrm{BF}_{4}\right]$ increased with an increase in water content, while that in $\left[\mathrm{C}_{2} \mathrm{mim}\right][\mathrm{FSI}]$ decreased with increasing water content. When a certain amount of water is added into the nonaqueous enzymatic reaction system, some water is bound to the enzyme, and thereby has a large influence on the

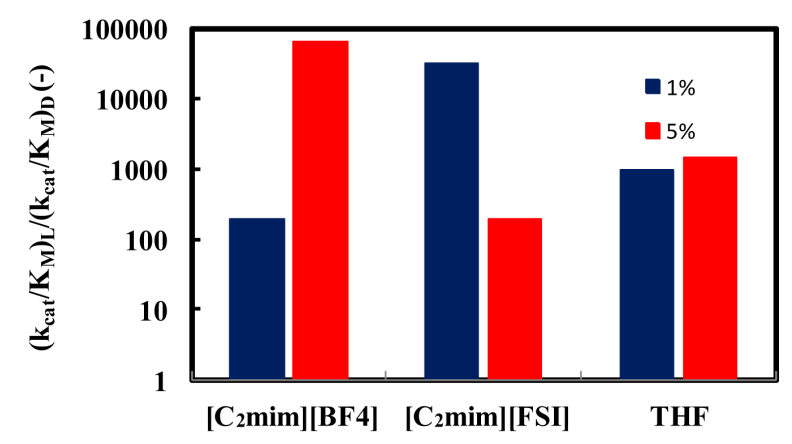

Figure 3. Effect of water content on the enantioselectivity of $\alpha$-chymotrypsin in the esterification of $\mathrm{N}$-Ac-Trp-OH with EtOH in $\left[\mathrm{C}_{2} \mathrm{mim}\right]\left[\mathrm{BF}_{4}\right],\left[\mathrm{C}_{2} \mathrm{mim}\right][\mathrm{FSI}]$, and THF. The enzyme was placed in the solvent containing a certain amount of water, 5 - $25 \mathrm{mM} \mathrm{N}$-Ac-Trp-OH, and $1000 \mathrm{mM}$ $\mathrm{EtOH}$, and the resulting mixture was shaken at $120 \mathrm{rpm}$ and $25^{\circ} \mathrm{C}$. enzyme performance, while the other amount of water is dissolved in the solvent [1]. Water associated with the enzyme activates the enzyme by increasing the internal flexibility of the enzyme molecule, since water acts as a plasticizer to increase the flexibility [14]. The optimum water content for the enzyme performance is due to the balance between kinetic rigidity and thermodynamic stability of enzyme structures, and is called essential water [15]. The kinetic rigidity is relaxed by increasing water content, while native enzyme structure gradually changes through thermodynamic stability. For instance, the activity increases with an increase in the flexibility of rigid enzyme in ionic liquids, and it decreases with an increase in disturbance of enzyme structure [9]. Since the water solubility of $\left[\mathrm{C}_{2} \mathrm{mim}\right][\mathrm{FSI}]$ is much lower than that of $\left[\mathrm{C}_{2} \mathrm{mim}\right]\left[\mathrm{BF}_{4}\right]$, the distribution of water to the enzyme molecule in $\left[\mathrm{C}_{2} \mathrm{mim}\right][\mathrm{FSI}]$ is superior to that in $\left[\mathrm{C}_{2} \mathrm{mim}\right]$ $\left[\mathrm{BF}_{4}\right]$. Consequently, at $5 \%(v / v)$ water the disturbance of enzyme structure might be enhanced to some extent in $\left[\mathrm{C}_{2} \mathrm{mim}\right][\mathrm{FSI}]$ system, since the water solubility of $\left[\mathrm{C}_{2} \mathrm{mim}\right]$ $[\mathrm{FSI}]$ is $3.45 \%$. On the other hand, $\left[\mathrm{C}_{2} \mathrm{mim}\right]\left[\mathrm{BF}_{4}\right]$ system exhibited the same tendency in the relation between the water content and the enantioselectivity as THF system. $\left[\mathrm{C}_{2} \mathrm{mim}\right]\left[\mathrm{BF}_{4}\right]$ and THF systems was probably in the relax of kinetic rigidity at $5 \%(v / v)$ water, since $\left[\mathrm{C}_{2} \mathrm{mim}\right]$ $\left[\mathrm{BF}_{4}\right]$ and THF are water soluble.

\subsection{Effect of Reaction Temperature on Enantioselectivity of $\alpha$-Chymotrypsin in Ionic Liquids}

Enzymatic reactions, as well as chemical reactions, obey the Arrhenius correlation between reaction rate constant and temperature, although the temperature range is quite limited. Accordingly, it is considered that the enantioselectivity is strongly influenced by the reaction temperature. In order to estimate the effect of reaction temperature on $\alpha$-chymotrypsin-catalyzed esterification in ionic liquids, the enantioselectivity in ionic liquids and THF containing 5\% (v/v) water was investigated at different temperatures. Figure 4 shows the enantioselectivity of $\alpha$-chymotrypsin in the esterification of $N$-Ac-Trp-OH with EtOH in ionic liquids and THF at different reaction temperatures. The enantioselectivity of $\alpha$-chymotrypsin in $\left[\mathrm{C}_{2} \mathrm{mim}\right]\left[\mathrm{BF}_{4}\right]$ at $40^{\circ} \mathrm{C}$ was lower than that at $25^{\circ} \mathrm{C}$, while that in $\left[\mathrm{C}_{2} \mathrm{mim}\right][\mathrm{FSI}]$ increased with increasing the reaction temperature. On the other hand, the enantioselectivity of $\alpha$-chymotrypsin in THF dropped with an increase in the reaction temperature. The temperature dependence of the enantioselectivity of protease and lipase is markedly affected by organic solvents [3]. Thus, the result indicates that the temperature dependence of the enantioselectivity is controlled by changing the reaction medium from one ionic liquid to another, similar to the 
case of organic solvents.

\subsection{Relation between the Reactivity and Enantioselectivity of $\alpha$-Chymotrypsin in Ionic Liquids}

As mentioned above, the enantioselectivity is strongly influenced by ionic liquids, water content, and reaction temperature. In order to assess the correlation between the enzyme reactivity and the enantioselectivity, the $\left(k_{\text {cat }} / K_{\mathrm{M}}\right)_{\mathrm{L}} /\left(k_{\text {cat }} / K_{\mathrm{M}}\right)_{\mathrm{D}}$ ratio was plotted against the $\left(k_{\text {cat }} / K_{\mathrm{M}}\right)_{\mathrm{L}}$ value, as seen in Figure 5. One can observe an increase in the $\left(k_{\text {cat }} / K_{\mathrm{M}}\right)_{\mathrm{L}} /\left(k_{\text {cat }} / K_{\mathrm{M}}\right)_{\mathrm{D}}$ ratio with increasing the $\left(k_{\text {cat }} / K_{\mathrm{M}}\right)_{\mathrm{L}}$ value. The specificity constant $\left(k_{\text {cat }} / K_{\mathrm{M}}\right)_{\mathrm{L}}$ is attributable to the enzyme structure [11]. Therefore, the higher the native structure of en-

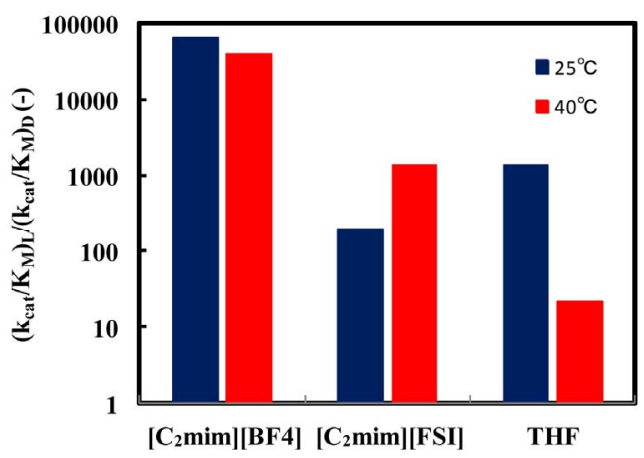

Figure 4. Effect of reaction temperature on the enantioselectivity of $\alpha$-chymotrypsin in the esterification of $\mathrm{N}$-Ac-Trp-OH with EtOH in $\left[\mathrm{C}_{2} \mathrm{mim}\right]\left[\mathrm{BF}_{4}\right]$, $\left[\mathrm{C}_{2} \mathrm{mim}\right][\mathrm{FSI}]$, and THF. The enzyme was placed in the solvent containing $5 \%(v / v)$ water, $5-25 \mathrm{mM}$ $\mathrm{N}$-Ac-Trp-OH, and $1000 \mathrm{mM} \mathrm{EtOH}$, and the resulting mixture was shaken at $120 \mathrm{rpm}$ and 25 and $40^{\circ} \mathrm{C}$.

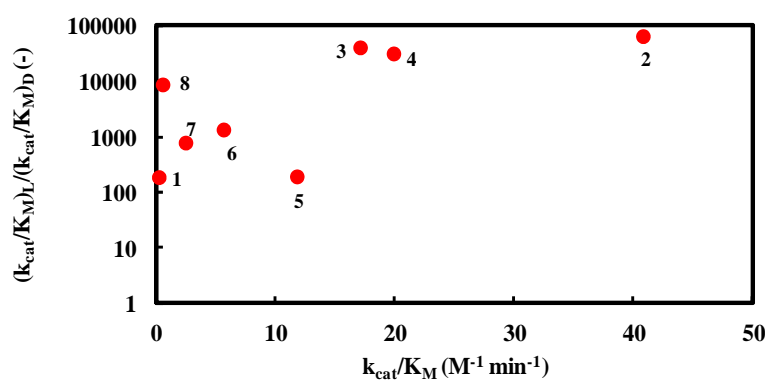

Figure 5. Dependence of the enantioselectivity of $\alpha$-chymotrypsin in the esterification of $N$-Ac-Trp-OH with EtOH on its specificity constant. The enzyme was placed in the solvent containing a certain amount of water, 5 - $25 \mathrm{mM} \mathrm{N}$-Ac-Trp-OH, and $1000 \mathrm{mM} \mathrm{EtOH}$, and the resulting mixture was shaken at an appropriate temperature. Reaction conditions: (1) $1 \%(v / v)$ water and $25^{\circ} \mathrm{C}$ in $\left[\mathrm{C}_{2} \mathrm{mim}\right]\left[\mathrm{BF}_{4}\right],(2) 5 \%(v / v)$ water and $25^{\circ} \mathrm{C}$ in $\left[\mathrm{C}_{2} \mathrm{mim}\right]\left[\mathrm{BF}_{4}\right],(3) 5 \%(v / v)$ water and $40^{\circ} \mathrm{C}$ in $\left[\mathrm{C}_{2} \mathrm{mim}\right]\left[\mathrm{BF}_{4}\right]$, (4) $1 \%(v / v)$ water and $25^{\circ} \mathrm{C}$ in $\left[\mathrm{C}_{2} \mathrm{mim}\right][\mathrm{FSI}],(5) 5 \%(v / v)$ water and $25^{\circ} \mathrm{C}$ in $\left[\mathrm{C}_{2} \mathrm{mim}\right][\mathrm{FSI}],(6) 5 \%(v / v)$ water and $40^{\circ} \mathrm{C}$ in $\left[\mathrm{C}_{2} \mathrm{mim}\right][\mathrm{FSI}]$, (7) $5 \%(v / v)$ water and $25^{\circ} \mathrm{C}$ in $\left[\mathrm{C}_{4} \mathrm{mim}\right]\left[\mathrm{PF}_{6}\right]$, (8) $5 \%(v / v)$ water and $25^{\circ} \mathrm{C}$ in $\left[\mathrm{C}_{4} \mathrm{mim}\right][\mathrm{TFSI}]$. zymes is kept, the larger the $\left(k_{\text {cat }} / K_{\mathrm{M}}\right)_{\mathrm{L}} /\left(k_{\text {cat }} / K_{\mathrm{M}}\right)_{\mathrm{D}}$ ratio becomes.

\section{CONCLUSION}

We have demonstrated that $\alpha$-chymotrypsin exhibits the wide enantioselectivity in the esterification of $N$-AcTrp-OH with ethanol in ionic liquids. The kind of ionic liquids strongly affected the enantioselectivity of $\alpha$ chymotrypsin. The enantioselectivity of $\alpha$-chymotrypsin markedly depended upon the water content in $\left[\mathrm{C}_{2} \mathrm{mim}\right]$ $\left[\mathrm{BF}_{4}\right]$ and $\left[\mathrm{C}_{2} \mathrm{mim}\right][\mathrm{FSI}]$, similar to THF. When the water content was $5 \%(v / v)$, the enantioselectivity in $\left[\mathrm{C}_{2} \mathrm{mim}\right]\left[\mathrm{BF}_{4}\right]$ was much superior to that in THF. The temperature dependence of enantioselectivity was remarkably influenced by ionic liquids. These results indicate that the enantioselectivity can finely be controlled by selected conditions in ionic liquids.

\section{REFERENCES}

[1] Klibanov, A.M. (2001) Improving enzymes by using them in organic solvents. Nature, 409, 241-246. http://dx.doi.org/10.1038/35051719

[2] Noritomi, H., Sasanuma, A., Kato, S. and Nagahama, K. (2007) Catalytic properties of cross-linked enzyme crystals in organic media. Biochemical Engineering Journal, 33, 228-231. http://dx.doi.org/10.1016/j.bej.2006.10.024

[3] Noritomi, H., Almarsson, Ö., Barletta, G.L. and Klibanov, A.M. (1996) The influence of the mode of enzyme preparation on enzymatic enantioselectivity in organic solvents and its temperature dependence. Biotechnology and Bioengineering, 51, 95-99.

http://dx.doi.org/10.1002/(SICI)1097-0290(19960705)51: $1<95::$ AID-BIT11>3.0.CO;2-3

[4] Wescott, C.R., Noritomi, H. and Klibanov, A.M. (1996) Rational control of enzymatic enantioselectivity through solvation thermodynamics. Journal of the American Chemical Society, 118, 10365-10370. http://dx.doi.org/10.1021/ja961394q

[5] Kise, H., Hayakawa, A. and Noritomi, H. (1990) Protease-catalyzed synthetic reactions and immobilization-activation of the enzymes in hydrophilic organic solvents. Journal of Biotechnology, 14, 239-254. http://dx.doi.org/10.1016/0168-1656(90)90110-W

[6] Kokorin, A. (2011) Ionic liquids: Applications and perspectives. InTech, Rijeka. http://dx.doi.org/10.5772/1782

[7] Moniruzzaman, M., Nakashima, K., Kamiya, N. and Goto, M. (2010) Recent advances of enzymatic reactions in ionic liquids. Biochemical Engineering Journal, 48, 295 314. http://dx.doi.org/10.1016/j.bej.2009.10.002

[8] Noritomi, H., Nishida, S. and Kato, S. (2007) Proteasecatalyzed esterification of amino acid in water-miscible ionic liquid. Biotechnology Letters, 29, 1509-1512. http://dx.doi.org/10.1007/s10529-007-9416-4

[9] Noritomi, H., Suzuki, K., Kikuta, M. and Kato, S. (2007) 
Catalytic activity of $\alpha$-chymotrypsin in enzymatic peptide synthesis in ionic liquids. Biochemical Engineering Journal, 47, 27-30.

http://dx.doi.org/10.1016/j.bej.2009.06.010

[10] Kumar, A. and Venkatesu, P. (2012) Overview of the stability of $\alpha$-chymotrypsin in different solvent media. Chemical Reviews, 112, 4283-4307.

http://dx.doi.org/10.1021/cr2003773

[11] Fersht, A. (1999) Structure and mechanism in protein science: A guide to enzyme catalysis and protein folding. W. H. Freeman and Company, New York.

[12] Segel, I.H. (1993) Enzyme kinetics: Behavior and analy- sis of rapid equilibrium and steady-state enzyme systems. John Wiley \& Sons, Inc., New York.

[13] Noritomi, H., Minamisawa, K., Kamiya, R. and Kato, S. (2011) Thermal stability of proteins in the presence of aprotic ionic liquids. Journal of Biomedical Science and Engineering, 4, 94-99. http://dx.doi.org/10.4236/jbise.2011.42013

[14] Zaks, A. and Klibanov, A.M. (1988) The effect of water on enzyme action in organic media. The Journal of Biological Chemistry, 263, 8017-8021.

[15] Klibanov, A.M. (1986) Enzymes that work in organic solvents. Chemtech, 16, 354-359. 